\title{
Break Even Point Analysis As A Basic of Profit Planning In Handal Insan Sentosa Batik Business
}

\author{
Ucik Arfianti*, Reswanda
}

Faculty of Economy and Business, Narorama University, Surabaya, Indonesia

\begin{abstract}
Batik is a craft that has high artistic value and has been a part of Indonesian culture for a long time. One of the centers of written batik in Sidoarjo is Reliable Insan Sentosa written batik which is a container in the effort to preserve batik itself. This study aims to analyze the amount of company revenue and production in the state of reaching Break Even Point. The method used in this study is a qualitative descriptive method, to get a clearer and more detailed picture based on the data and information that has been obtained. The results showed that the business of reliable handmade batik sentosa level of profit earned Rp. 12,182,325, where the break even point of sales achieved was Rp.199,000,000 with a total of 199 units. The achieved margin of safety is $10 \%$ or Rp.22,200,000 from sales. So that the margin of safety obtained is Rp.199,800,000. In this case the greater the margin of safety the better for the company because the company can experience a significant decline. MSMEs are advised to classify costs to prepare financial reports and apply a BEP analysis to determine financial condition.
\end{abstract}

Keywords: break even point, margin of safety, profit planning.

\section{Preliminary}

\subsection{Background}

In fostering economic growth, the MSMEs have a large contribution, especially in developing countries. Impacts that have a positive effect can drive the wheels of the nation's economy and reduce the amount of unemployment. In Indonesia, MSME is one of the drivers in economic development which is considered to be very flexible and easy to adapt to market demand. SMEs themselves are very fast job creators compared to other business sectors. In general, the existence of MSMEs is a potential in every region, because this business has a significant role in absorbing the workforce and local people's source of income. In the era of modernization and globalization, it turns out that traditional batik is still loved and preserved by people who have global and modern insight. Thus, batik must remain preserved and maintained so that it remains a characteristic of Indonesia. Being a superior local product not only in the country but to foreign countries with a variety of diversity that batik has. Batik can be divided into several types including: written batik, printed batik, a combination of stamp and write, batik printing. One of them is Jetis traditional batik village in Sidoarjo Regency. Its location in downtown Sidoarjo.

One of the batik crafters in Sidoarjo that still preserves this culture is Handala Insan Sentosa Batik which is located at Jetis Gg. II / 70 Sidoarjo Public Corporation. Taman Puspa Sari G.16, Kali Pecabean Candi - Sidoarjo. The craftsman industry is one that is quite well known in the city of Sidoarjo. It is expected that business people can analyze about their profit planning, planning is very important in achieving profits for the survival of a business. It is necessary to analyze the costs, sales volume, selling price and profit planning, one of which is to use the Break Even Point (BEP) analysis technique, which is a point where the business does not make a profit or no loss or profit equal to zero or the total revenue equals the total cost. Through Break Even Point, Insan Sentosa's Reliable Batik Business can easily

\footnotetext{
* Corresponding author.

E-mail address: ucikarfianti@gmail.com (Ucik Arfianti)
} 
determine the sales volume needed to achieve the desired profit level. It also will obtain information on the minimum level of sales that must be achieved so as not to experience a loss. Information about the margin of safety can be expressed as a percentage or ratio between budgeted sales and sales volume at the break-even level. Margin of safety is a tool that can provide information about how much of the budgeted sales volume or certain sales results may go down so that the company does not suffer losses. Thus, the margin of safety is a requirement to know the safety limits of the conditions of sale and it can also be known how much must be produced so that sales approach the breakeven point. The purposes of this study: (1) to find out the level of profit achieved by Insan Sentosa Reliable Batik; (2) to find out the level of margin of safety in the Insan Sentosa Reliable Batik Business.

\section{Literature Review}

\subsection{Break Even Point}

According to (Simamora, 2012), BEP or break-even point is the sales volume where the amount of revenue and total expenses are the same, there is no net profit or loss.

\subsection{Cost}

According to (Simamora, 2002), Cost is cash or the cash equivalent value sacrificed for goods or services that are expected to provide benefits at this time or in the future for the organization.

\subsection{Sales}

According to (Mulyadi, 2008) sales are activities carried out by sellers in selling goods or themselves in the hope that they can benefit from such transactions.

\subsection{Profit Planning}

According to Panomban (2016) Earnings planning is a work plan that has been calculated in the form of the calculation of profit and loss, balance sheet, and working capital for the short term and long term

\subsection{Margin of Safety or Safety Margin}

According to (Garisson, Noreen, \& Brewer, 2014) the margin of safety is the excess of the sales value in rupiah that is budgeted above the break-even point of sale in rupiah.

\subsection{Contribution Margin}

According to (Garrison, Noreen, \& Brewer, 2013) the contribution margin is the sum of sales revenue minus variable expenses.

\subsection{Prior Research}

Tirajoh, Sabijono, \& Mangundap (2014) examined the break even point as a short-term profit planning tool for shimily cupcakes. The purpose of this research is to find out the use of BEP analysis tools in planning and further increasing company profits. The results explain that companies taking into account the margin of safety and contribution margin can maximize the break even point method as a method for selling above the break-even point and minimizing losses. The break even point level achieved by Shmily Cupcakes home industry on sales can reach above average profits. It shows that the owner has sold above the breakeven point and obtained a lot of profit. Owner Shmily Cupcakes should apply the BEP analysis as one of the tools to determine the financial condition that has been achieved. 


\section{Research Methods}

\subsection{Research Approach}

This research used a descriptive qualitative research method with a case study approach. Qualitative descriptive research is research that illustrates or depicts the object of research based on facts that appear or as they are.

\subsection{Object of research}

In this study, the object or place of research is Insan Sentosa Reliable Batik located in Jetis Gg. II / 70 Sidoarjo 61213 Public Corporation. Taman Puspa Sari G.16, Kali Pecabean Candi - Sidoarjo.

\subsection{Data analysis technique}

According to Lexy J. Moleong, the process of qualitative data analysis begins by examining all available data from various sources, namely interviews, observations that have been written in field notes, photographs and so on. The following stages are:

1. Data Reduction

Reducing data means summarizing, choosing the main points, focusing on the important things. Thus, the purpose of data reduction is to simplify the data obtained during data mining in the field.

2. Data Presentation

Presentation of data is a collection of structured information that gives the possibility of drawing conclusions. Presentation of data is done to be able to see the overall picture or certain parts of the overall picture.

3. Conclusion or Verification

Conclusions or final stages of verification in the data analysis process. In this section the researcher expresses conclusions from the data that has been obtained. This activity is intended to find the meaning of data collected by looking for relationships, similarities, or differences. Conclusions can be drawn by comparing the suitability of the statement of the research subject with the meaning contained with the basic concepts in the study.

4. Triangulation

is a data validity checking technique that utilizes something else in comparing the results of research object interviews (Moloeng, 2004; 330). Triangulation can be done using different techniques (Nasution, 2003: 115), namely interviews, observations and documents. Triangulation is used to check the truth and reproduce data. According to Nasution, besides triangulation to investigate the validity of researchers' interpretation of the data, triangulation is therefore reflective.

\subsection{Data source}

The data source used is primary data where researchers directly conduct research on reliable written batik business people. Primary data is a source of research data obtained directly from the original source (not through an intermediary).

\subsection{Data collection technique}

a) Field Study

Conducting direct observations and interviews on reliable batik businessman sentosa.

b) Observation

Activities of a process or object with the intention of feeling and then understanding the knowledge of a phenomenon based on previously known knowledge and ideas, to obtain the information needed to continue a study. This method the author uses to observe physical and non-physical conditions in the form of places, buildings in a reliable insane sentosa handmade batik business. 
c) Interview

Is a conversation between two or more people and takes place between the interviewee and interviewer. The purpose of the interview is to get the right information from trusted sources. Interviews were conducted by submitting a number of questions from the interviewer to a reliable business owner of batik insane sentosa.

d) Documentation

From the documentation process, the data obtained are photographs as a support. Documentation is a method used to provide documents using accurate evidence from the recording of information sources.

e) Literature Study

Literature study is an activity to gather information that is relevant to the topic or problem that is the object of research. Such information can be obtained from books, scientific papers, theses, dissertations, the internet and other sources. The role of library studies before research is very important because by carrying out these activities the relationship between problems, relevant research and theory will become clearer. In addition, research will be more supported, both by existing theories and by concrete evidence, namely research results, conclusions and suggestions.

In this case, the calculations used in this study are as follows:

1. Calculation of profit

Perform calculations of each cost, namely variable costs and fixed costs.

2. Calculation of break even points

Conduct a classification of each variable cost and fixed costs to calculate the selling price, sales volume, and margin of safety.

3. Break Even Point Calculation Formulas:

On Unit Basis:

$$
\text { break even point }=\frac{\text { fixed cost }}{\text { selling price per unit }- \text { variable cost per unit }}
$$

On Rupiah Basis:

Break even point $=$ per unit $\mathrm{x}$ selling price

Margin Of Safety Calculation Form:

$$
\text { margin of safety } \%=\frac{\text { total sales }- \text { break even point sales }}{\text { total sales }}
$$

Rumus Perhitungan Contribution Margin:

$$
\text { contribution margin }=-\frac{\text { selling variabel }}{\text { selling }}
$$

\begin{tabular}{|c|c|c|}
\hline Cost & Fix Cost & Variable Cost \\
\hline \multicolumn{3}{|l|}{ Cost of goods sold } \\
\hline Raw materials costs & & 17.000 .000 \\
\hline Direct labor cost & & 42.960 .000 \\
\hline Factory overhead costs & & 18.110 .000 \\
\hline Cost of supporting materials & & 84.000 \\
\hline
\end{tabular}

\section{Results and Discussion}

Table 1 Separation of variable costs and fixed costs in 2019 


\begin{tabular}{lrr}
\hline Cost & Fix Cost & Variable Cost \\
\hline Consumable materials costs & & 15.600 .000 \\
\hline Total HPP & & $\mathbf{9 3 . 7 5 4 . 0 0 0}$ \\
\hline Operating cost & 4.040 .000 & \\
\hline Electricity cost & 840.000 & \\
Telephone charge & 4.320 .000 & \\
Kerosene cost & 3.000 .000 & \\
Water cost & 150.000 & \\
Maintenance cost & 31.072 .500 & \\
Cost of depreciation & 72.000 .000 & \\
Salary expense & $\mathbf{1 1 5 . 4 2 2 . 5 0 0}$ & \\
\hline Total operating cost & & $\mathbf{2 0 9 . 1 7 6 . 5 0 0}$ \\
\hline Total cost & & \\
\hline
\end{tabular}

Table 2 Income statement in 2019

\begin{tabular}{|c|c|c|}
\hline Selling & & 222.000 .000 \\
\hline \multicolumn{3}{|l|}{ Cost of good sold } \\
\hline Raw materials cost & 17.000 .000 & \\
\hline Factory overhead cost & 18.110 .000 & \\
\hline Cost of supporting & 84.000 & \\
\hline Consumable material cost & 15.600 .000 & \\
\hline Direct labor cost & 42.960 .000 & \\
\hline Total cost of good sold & & 93.754 .000 \\
\hline Gross profit & & 128.246 .000 \\
\hline \multicolumn{3}{|l|}{ Operating cost } \\
\hline Electric cost & 4.040 .000 & \\
\hline Water cost & 3.000 .000 & \\
\hline Koresene cost & 4.320 .000 & \\
\hline Telephone charge & 840.000 & \\
\hline Care and maintenance cost & 150.000 & \\
\hline Cost of depriciation & 31.072 .500 & \\
\hline Salary expense & 72.000 .000 & \\
\hline Total operating cost & & 115.422 .500 \\
\hline Profit before tax & & 12.823 .500 \\
\hline Tax $0,5 \%$ & & 641.175 \\
\hline Nett profit & & 12.182 .325 \\
\hline
\end{tabular}

Source: Batik Business Handal Insan Sentosa, 2019

\subsection{Analysis Contribution Margin}

Contribution margin is the difference between sales and variable costs of a product or service. That is the amount of money available to cover fixed costs and generate profits. Here is the contribution margin formula:

Contribution margin $=$ sales - variable costs

Unit contribution margin $=$ selling price per unit - variable cost per unit 
Table 3 Contribution margin calculation

\begin{tabular}{|c|c|c|}
\hline & Total & Per unit \\
\hline Sales & 222.000 .000 & 1.000 .000 \\
\hline Variable cost & (93.754.000) & $(422.315)$ \\
\hline Contribution margins & 128.246 .000 & 577.685 \\
\hline Fixed cost & $(115.422 .500)$ & \\
\hline Nett profit & 12.823 .500 & \\
\hline
\end{tabular}

$$
\begin{gathered}
\text { contribution margins ratio }=\frac{\text { contribution margin }}{\text { sale }} \\
\frac{128.246 .000}{222.000 .000}=0,57 \text { or } 57 \%
\end{gathered}
$$

In 2019 the reliable written batik business of sentosa people has a contribution margin of 0.57 or $57 \%$ with sales of Rp.222,000,000. contribution margins of Rp.128,246,000 and 577,685 per unit. Then the profit is Rp. 12,823,500

\subsection{Break Even Point Analysis}

Break even point analysis is the point where the income from the business is equal to the capital spent, no loss or profit occurs. The following is a break-even point calculation on a reliable hand-made batik business, namely:

Break even point $($ per unit $)=$

fixed cost

$$
\begin{gathered}
\overline{\text { selling price per unit }- \text { cost variable per unit }} \\
\frac{115.422 .500}{1.000 .000-422.315}=199 \text { unit }
\end{gathered}
$$

Break even point $($ in rupiah $)=$

$$
\begin{aligned}
& =\text { per unit } x \text { selling price } \\
& =199 \times \mathrm{Rp} .1,000,000 \\
& =\mathrm{Rp} \cdot 199,000,000
\end{aligned}
$$

Based on the break-even point analysis, the business of reliable handmade batik sentosa has reached a position above the break-even point, where at the time the product units sold reached 199 units with sales of Rp.199,000,000 and at that time it did not make a profit or profit.

\subsection{Analysis of Margin of Safety or Safety Margin}

Margin of safety is information about to what extent a company may experience a decrease in sales but the company does not experience a loss. In this case the greater the margin of safety the better for the company because the company can experience a significant decline.

The following is a calculation of the margin of safety of a reliable written batik businessman sentosa:

$$
\text { margin of safety } \%=\frac{\text { total sale }- \text { break even point of sale }}{\text { total sale }}
$$




$$
\frac{222.000 .000-199.000 .000}{222.000 .000}=\frac{23.000 .000}{222.000 .000}=0,10 \text { atau } 10 \%
$$

Based on the above calculation, it can be seen that the maximum decrease that may occur in a reliable handmade batik business of sentosa is $10 \%$ or Rp. $22,200,000$ from sales. Thus, the margin of safety obtained was

Rp.199,800,000.

\section{Conclusion}

Based on the results of research and discussion that has been submitted, the following conclusions can be drawn:

1. The level of profit obtained Rp. 12,182,325 and a break even point that can be achieved by a Reliable Batik Insan Sentosa sidoarjo craftsman, the results obtained at the level of sales are sales of Rp.199,000,000 with a total of 199 units. It shows that the owner has sold above the breakeven point and made a profit.

2. Margin of safety shows the distance between planned sales and sales at the break even point. Thus the margin of safety also describes the distance limit, where the reduction in sales beyond the distance limit the company will suffer losses. Based on calculations made at the Insan Sentosa Reliable Batik Business in 2019, the margin of safety achieved was $10 \%$ or Rp.22,200,000 from sales. So the margin of safety gained is Rp.199,800,000

\section{References}

Brewer, G. N. (2006). Break Even Point. In Akuntansi Manajerial (14th ed., p. 335). Salemba Empat.

Garisson, Noreen, \& Brewer. (2014). Margin of Safety. In Akuntansi Manajerial (14th ed., p. 224). Salemba Empat.

Garrison, Noreen, \& Brewer. (2013). Margin Kontribusi. In Akuntansi Manajerial (14th ed., p. 209). Salemba Empat.

Harnanto. (2003). Pengertian Laba Secara Umum. In Akuntansi Keuangan Menengah (2003/2004, p. 444). Yogyakarta: Yogyakarta.

Mulyadi. (2001). Biaya. In Siistem Akuntansi (p. 8). Yogyakarta: Salemba Empat.

Mulyadi. (2005). Volume Penjualan. In Akuntansi Biaya (5th ed., p. 239). Yogyakarta: UPP AMP YKPN.

Mulyadi. (2008). Penjualan. In Auditing (6th ed., p. 202). Yogyakarta: Salemba Empat.

Simamora, H. (2002). Biaya. In Akuntansi Manajemen (2nd ed., p. 36). UPP AMP YKPN.

Simamora, H. (2012). BEP atau Titik Impas. In Manajemen Sumber Daya manusia (p. 170). Yogyakarta: STIE YKPN.

Tirajoh, V., Sabijono, H., \& Mangundap, R. (2014). Break Even Point Sebagai Alat Perencanaan Laba Jangka Pendek Pada Shmily Cupcakes. Jurnal Riset Ekonomi, Manajemen, Bisnis Dan Akuntansi, 2(4), 147-153. 